\title{
唾液腺多形性腺䀯の組織化学的研究
}

\author{
测 1. 次 蛅
}

\section{Histochemical studies of enzymes in salivary pleomorphic adenomas}

\author{
Jiro Okamoton
}

\section{I. 緒}

唾液腺の組䋐化学的研究はかなり穴くからあり，多灯

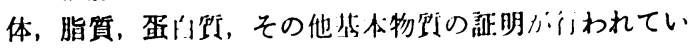
る.酵素組織化学の発注にともない，人および㺫乳酹物

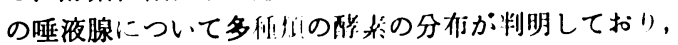
succinate dehydrogenase と系粒体，唾液腺，㗄管系の

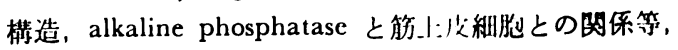
腺細胞の持つ酵素活性と腺機能との相略か：浟されてい

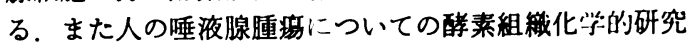
は Chauney, Shklar, Brooks (1962) ${ }^{11)}$, Murata, Miyaji $(1966)^{61)}$, Bruce, Wersheimer $(1967)^{6)}$, Mori, et al, $(1968)^{55)}$, Kaufman, Sticbity $(1969)^{27)}$, Lim., Mori $(1969)^{38)}$, Mira, Vidi (1970) ${ }^{42)}$ がある.

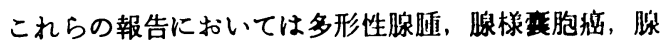

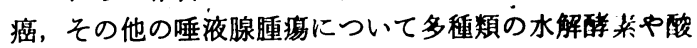
化酵素の組織化学的所見について述へている. 本論文は 唾液腺多形性腺腫の酵素について組織化学的分们を研究

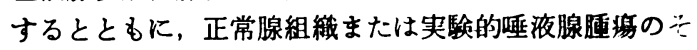
れらと比較検討した。

\section{II. 研 究 材 料}

酵素組織化学的に研究した唾液腺多形性腺腫はすでけ 詳述した臨床的病理組織学的研究63) と同一のむのであ る.

\section{組織化学的方法}

1) 材料の保存

生検または手術による摘出材粌よ付着している血派を 生理食塩水で流出しドライアイスで涷結し $-20^{\circ}$ ( : の低 温ストッカーに保存した。

2) 切片の作製

$-20^{\circ} \mathrm{C}$ クリスタット中にいれ sliding microtomi で約20枚の連続切片を作った．切片の厚さは $12 \mu$ であ

岐阜菌科大学口腔外科第一講座（主任：森 昌彦）

The First Department of Oral Surgery, Gifu Co-

llege of Dentistry (Chief: Prof. M. Mori)

受付日：昭和51年12月10日

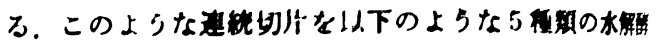

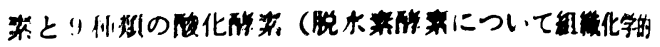

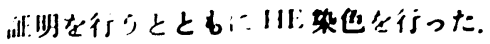

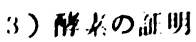

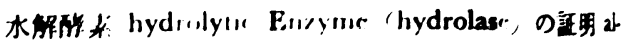
kaline phosphatase (AI.P), acidphosphatase (ACP), non-specific esteran (FST), ;-glucuronidase ";--Fase.

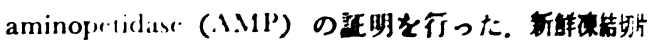

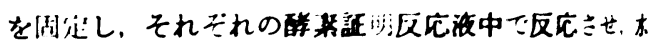
洗，站媒，ハルサ々封入を行った。

Alkaline phosphatase (ALP.

新鲜梠結切片を10\%ホルー・リンホで10分间固定し、

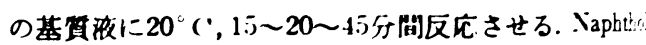

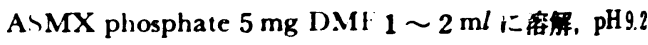
のClark. Lubs buffer $30 \mathrm{ml}$ を加六, Fast Red Vioke LB $30 \mathrm{mg}$ を整解する，使用直前に作る，醇素陽生部 は赤色となう。

\section{Acid phosphatase (AC'P}

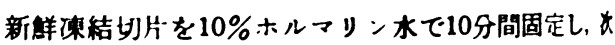

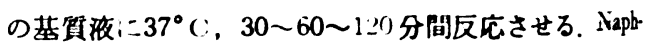
thol AS-TR phosphate $5 \mathrm{mg}$ を DMF К客儒, $\mathrm{pH} 5.8$ の $\mathrm{M} / 10,0.17$ V'eronal acetate buffer $30 \mathrm{ml}$ t加六 Fast Red Violet LB $30 \mathrm{mg}$ を客解する。醅素陽珄竐位 は暗赤色となる.

Esterase (non-specific esterase) (E.ST)

新鲜凍結切片を命アセトンて10分間固定し，次の基算 㳔に $37^{\circ} \mathrm{C} ， 30$ 一 60 年間反底させる. Naphthol AS-Da cetate $5 \mathrm{mg}$ を DMF に篎し， $\mathrm{pH}$ の M/100.17 Michaclis buffer または V'eronal buffer $30 \mathrm{ml}$ を加え Garnet GBC $30 \mathrm{mg}$ を解する，硣素晹性部位住赫 色より亦裸色となる。

;-(ilucronidase (;-(ia)

新解凍結切忏を10\%ホルシリン水で固定し，Post a 20 coupling 法で証明した。基質液は 6-bromo-2-naphthol $\beta$-D-glucuronide $5 \mathrm{mg}$ を methanol $5 \mathrm{ml}$ に容解し， pH 4.95 の M, 10 phospho-citric buffer $20 \mathrm{ml}$ および蒸 水 $75 \mathrm{ml}$ よりなる。この基質反応液に $37^{\circ} \mathrm{C} 6$ 時間反底 させ，水洗後 $4^{\circ} \mathrm{C} て ゙ 0.02 \mathrm{M}$ phosphate buffer $(\mathrm{pH} 7 . j$ に Diazo blue B を $1 \mathrm{mg} / 1 \mathrm{ml}$ の割合で溶解させた满 
に浸けると青色のアソ色素が形成される。 Aminopeptidase (AMP)

新鮮凍結切片を $10 \%$ ホルマリン水で固定し次の篦貿復 に37 ${ }^{\circ} \mathrm{C}, 20 \sim 60$ 分間反匛させる. L-leucyl- $\beta$-naphthylamine hydrochloride $1.0 \mathrm{ml}$ を $\mathrm{pH} 6.5$ の $0.1 \mathrm{M}$ acetale buffer $10.0 \mathrm{~m} l$ に溶解, $0.85 \% 8.0 \mathrm{ml} 2 \times 10^{-2} \mathrm{M} \mathrm{K(} \mathrm{N}$ $11.0 \mathrm{ml}$ を加え，Fast Blue B またはGamet GBC $1.0 \mathrm{mg}$

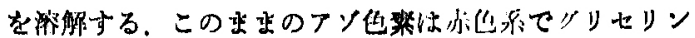

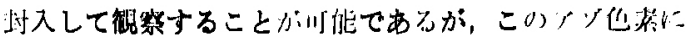
$0.1 \mathrm{M}$ 硫酸姛を加夫鍓キレートとして微祭してむ上い。

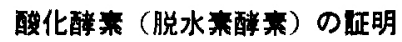

succinate dehydrogenase (il)l), litchate malall glu-

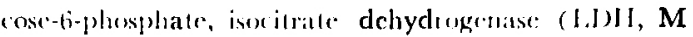
DH, ( 6 PDH, lDH) 特よび monoamine oxidase (M

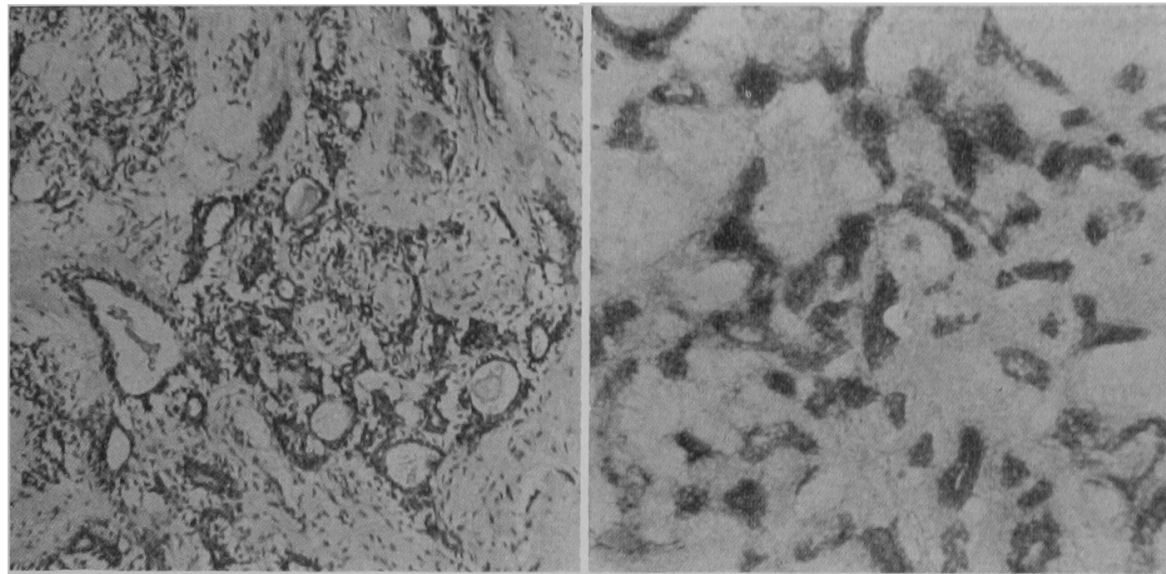

写真 1，2（1384）1. HE 染色 2. Alkaline phosphatasc $\times 100$ 多形腺腯の腺管梯 搆造を示す上皮䋨胞に强いALP 活性が認められる。

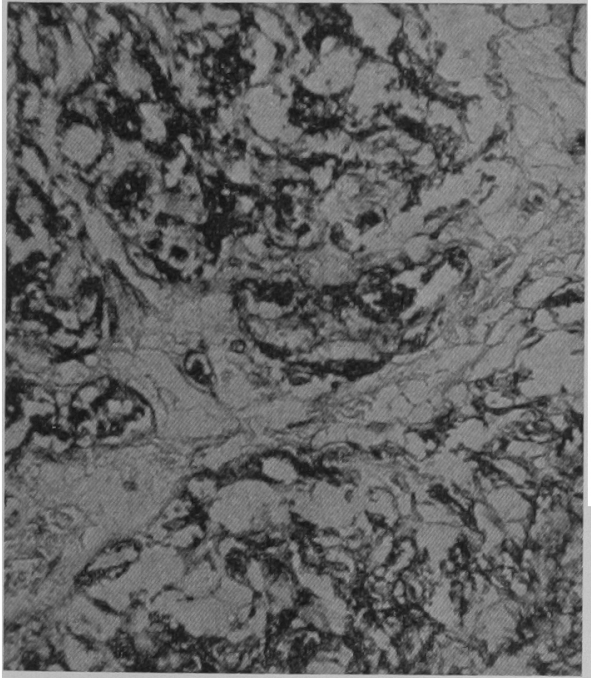

写直 3, 4, 5 (1443)

3. HE 染色

4. Alkaline phosphatase

5. Acid phosphatase $\times 100$ 多形性腺腫の董場勫胞に強いALP 活 性々 ACP 活性を示す症例。

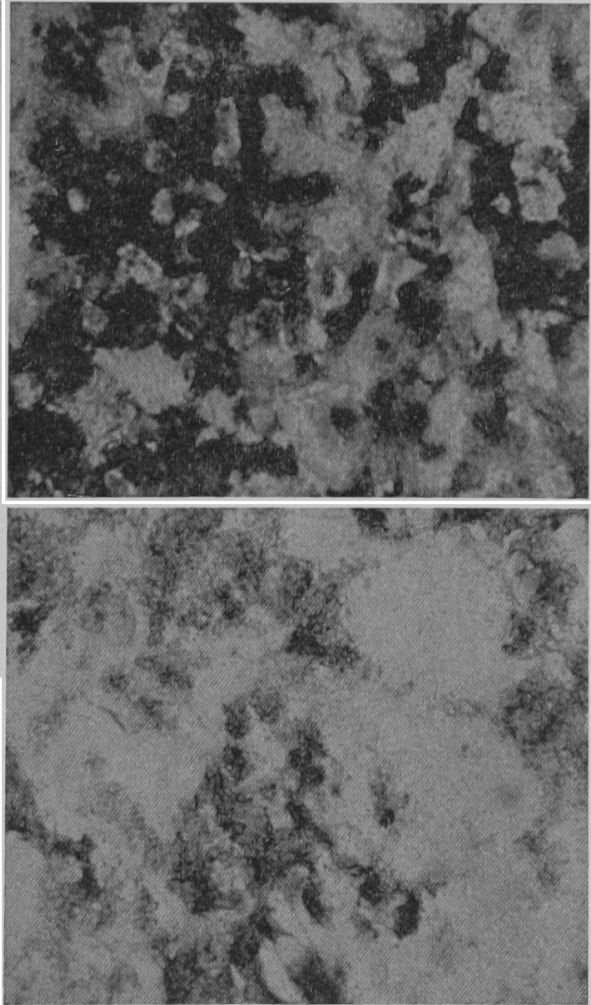




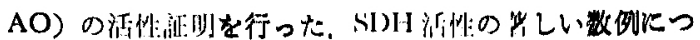
いては cytochrome oxidase の都明を汸小比门口た。

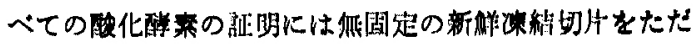

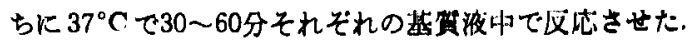

Succinate dehydrogenase (SDH)

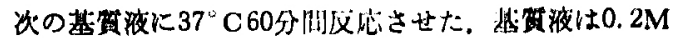
Sodium succinate $5 \mathrm{ml} \mathrm{pH} 7.6 の 0.2 \mathrm{M}$ phosphate buffer $5 \mathrm{ml}$, Nitro BT $(1 \mathrm{mg} / 1 \mathrm{ml}) 10 \mathrm{ml}$ よりる. 仪

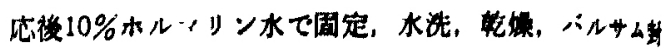
入した.

lactiale dehydrogenane (I.DH)

Malate dehydrogenase (MIH),

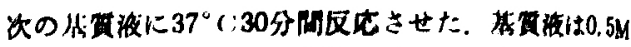
sodium lactale たは $1.0 \mathrm{M}$ sodium malate $4 \mathrm{ml}$, pht 7.4, 0.7 M phosphate buffer $11 \mathrm{ml}$, Nitro BT ( $5 \mathrm{mg} /$ $3 \mathrm{ml}) 3 \mathrm{ml}$, NAD $2.5 \mathrm{mg}$ 上りなる。
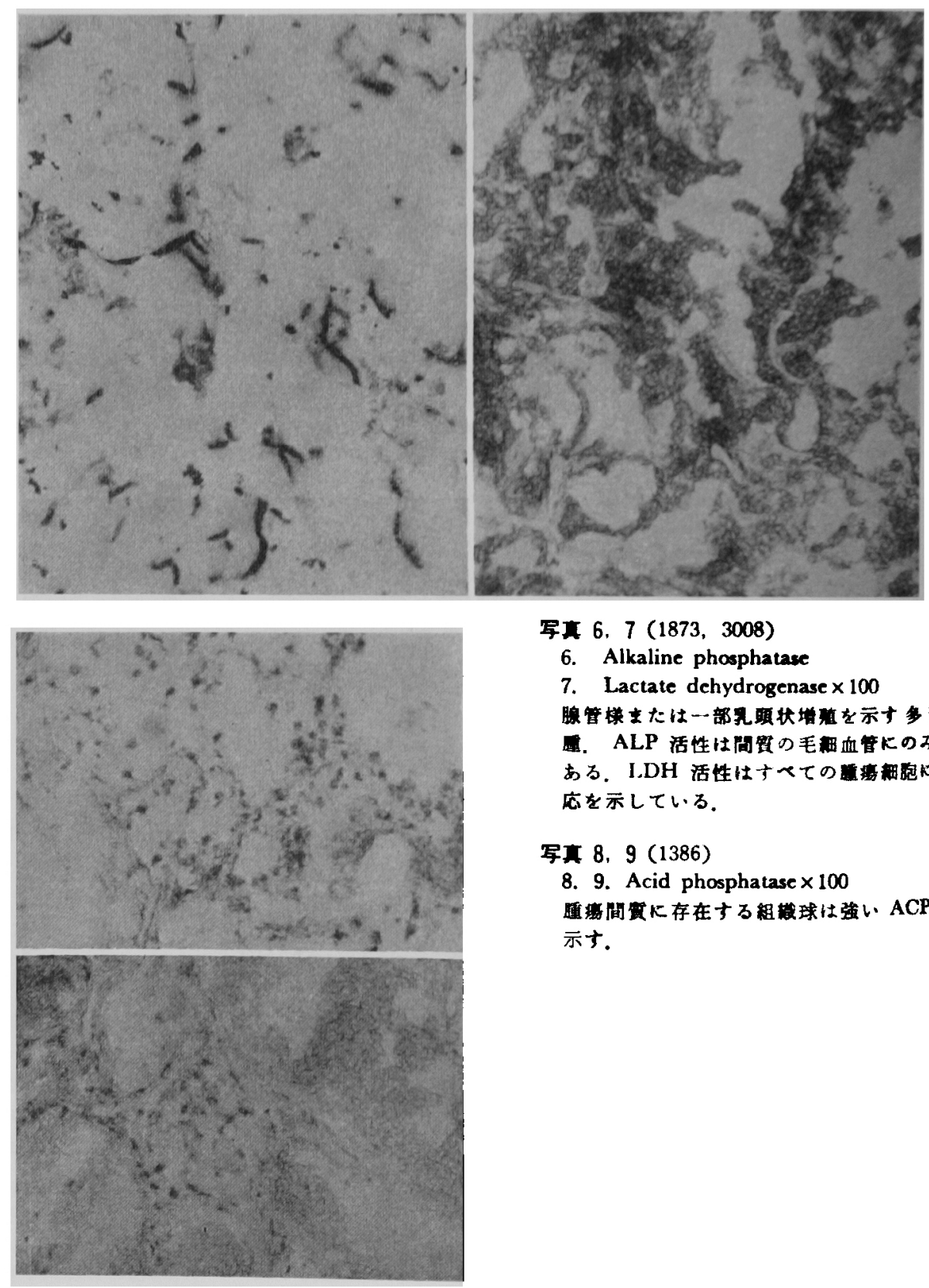

军卉 $6.7(1873,3008)$

6. Alkaline phosphatase

7. Lactate dehydrogenase $\times 100$

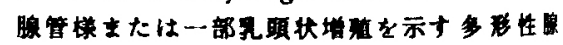

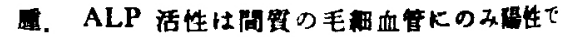

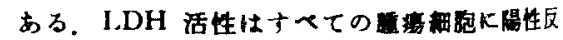
応を示している。

军亲 8, 9 (1386)

8. 9. Acid phosphatase $\times 100$

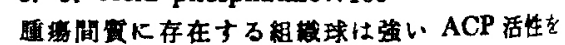
示す. 
Glucose-6-phosphate dehydrogenase (G 6 PDH) Isocitrate dehydrogenase (IDH)

次の基質液に $37^{\circ} \mathrm{C} 60$ 分間反応させた。基筫液は0.02 M disodium glucose-6-phosphate $4 \mathrm{ml}$ または $0.1 \mathrm{M}$ trisodium isocitrate $4 \mathrm{ml}, \mathrm{pH} 7.6 の 0.1 \mathrm{M}$ veronal acetate buffer $11 \mathrm{ml}$, Nitro BT ( $5 \mathrm{mg} / 3 \mathrm{ml}$ ) $3 \mathrm{ml}, \mathrm{N}$ "ADP $5 \mathrm{mg}(\mathrm{G} 6 \mathrm{PDH})$ または $2.5 \mathrm{mg}(\mathrm{IDH}), 0.5 \mathrm{M}$ $\mathrm{MnCl}_{2} 1.0 \mathrm{ml}, 0.001 \mathrm{M} \mathrm{MgCl} 21.0 \mathrm{ml}$ よりなる.この
液は pH7.2〜7.4に眮整する. veronal buffer の代りに Tris buffer 利用することができる。

Monoamine oxidase $(M \Lambda())$

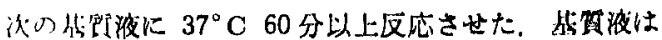
Triptamine hydrochloride $25 \mathrm{mg}, \mathrm{pH} 7.6$ の $0.1 \mathrm{M}$ phosphate buffer $5.0 \mathrm{~m} l$, Nitro BT (1.0mg/1.0ml) 5.0 $\mathrm{ml}$, 淩溜水 $15 \mathrm{ml}$ ，破酸ソーダ $4.0 \mathrm{~g}$ よりなる.

('yluchrome oxidase

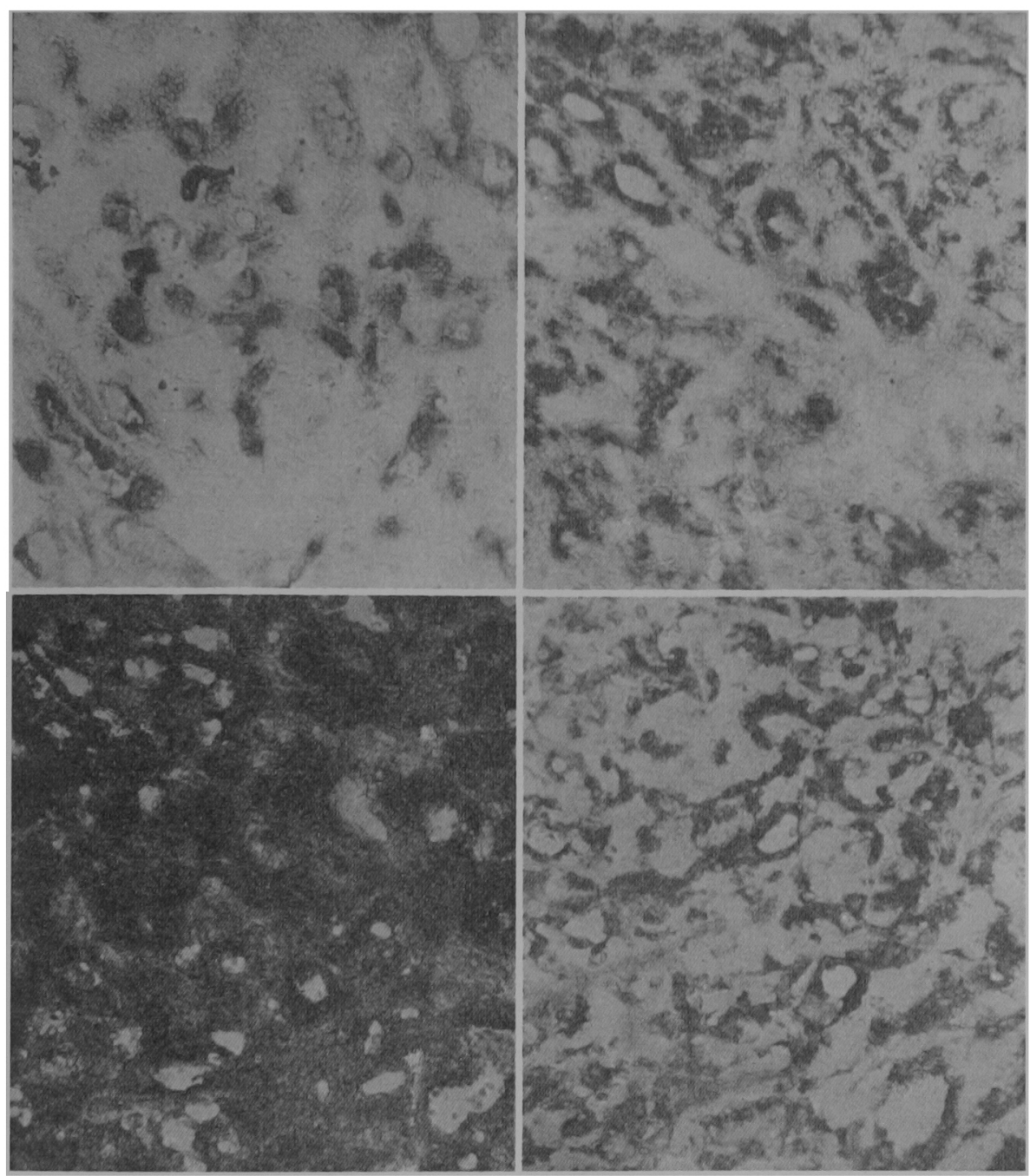

写真 $10,11,12,13$ (1169)

10. Alkaline phosphatase

11. Acid phosphatase

12. Lactate dehydrogenase

13. Glucose-6-phosphato dehydrogenase $\times 100$

小腺管様配列を示す多形性腺腫で，連瑒上皮の一部に ALP 活性を認め，大部分の線管 上皮稩胞に ACP 活性が陽性である。 LDH 活性は全体的に最強度陽性で，活性は線管 上皮の尰焬稩胞のみに陽性を示す。 


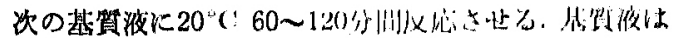
p-aminodiphenylanine $10 \mathrm{mg}$, p-me-1luxy-p-inminod:phenylamine (Variauniue: B 1 ue B) $10 \mathrm{mg}$ t $0.5 \mathrm{ml}=$

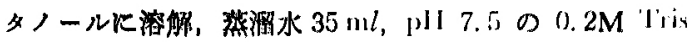

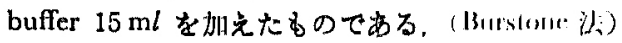

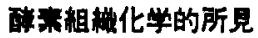

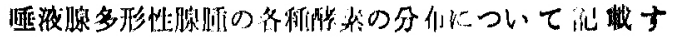
๖.

1. Alkaline plospluatast: (AIP)

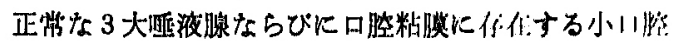

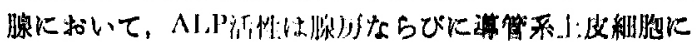

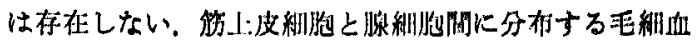

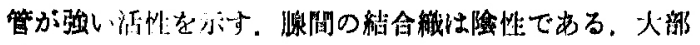

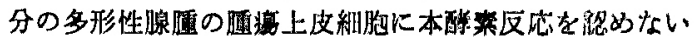

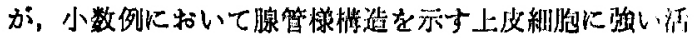

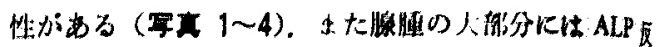

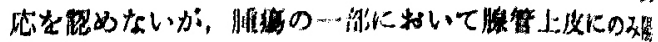

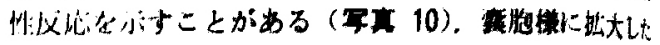

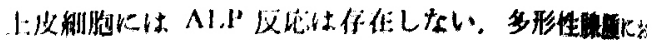

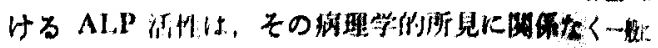

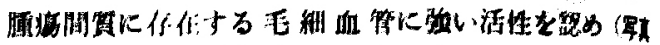

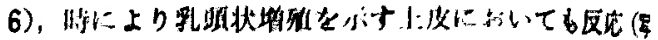

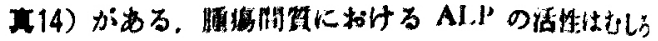

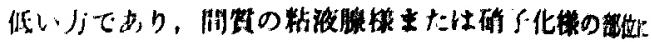
は砖められない。

2. Acid phosphatase (AC $[P)$

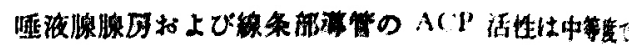

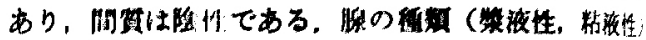

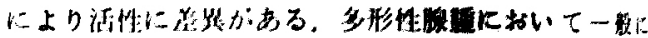

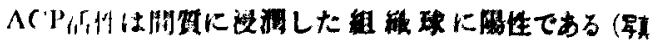

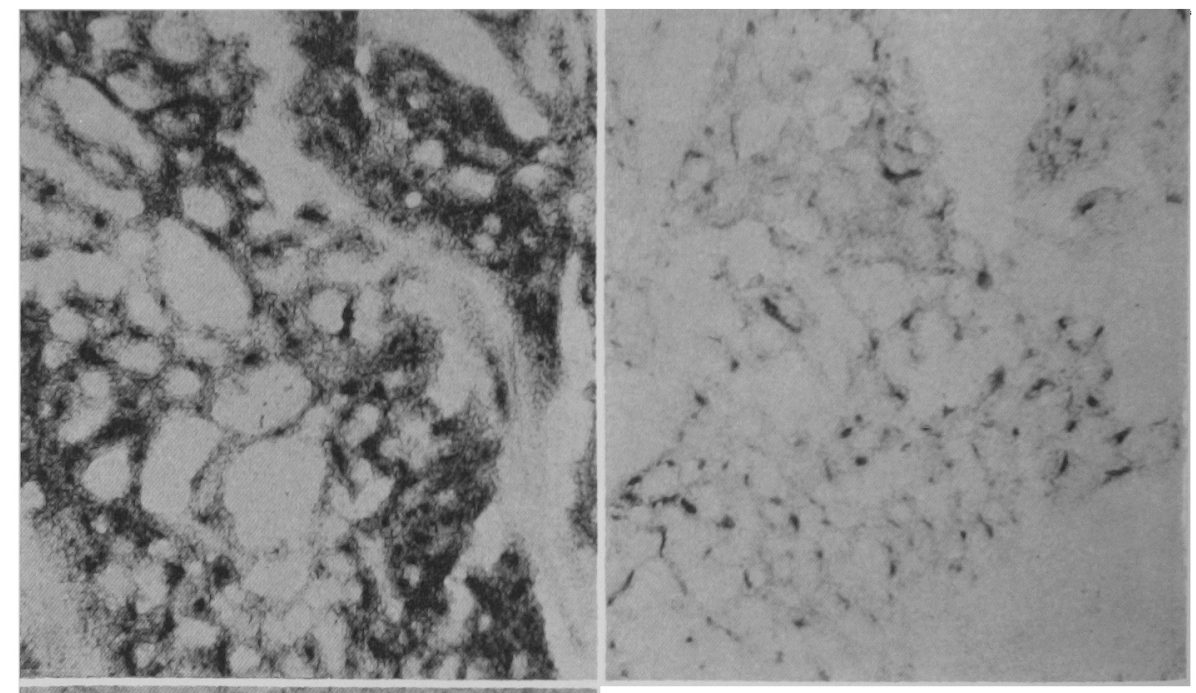

军卉 14, 15, 16 (1450)

14. Alkaline phosphatase

15. Acid phosphatase

16. Succinate dehydrogenase $\times 100$ 相かい線管㮞增㱠を示す多形性腺腫

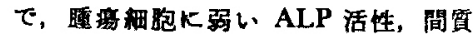

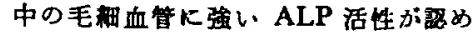
られる。ACP 活性は筷い閔留中に存 在する租阵球が陶性である. SDH 活

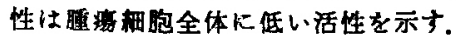



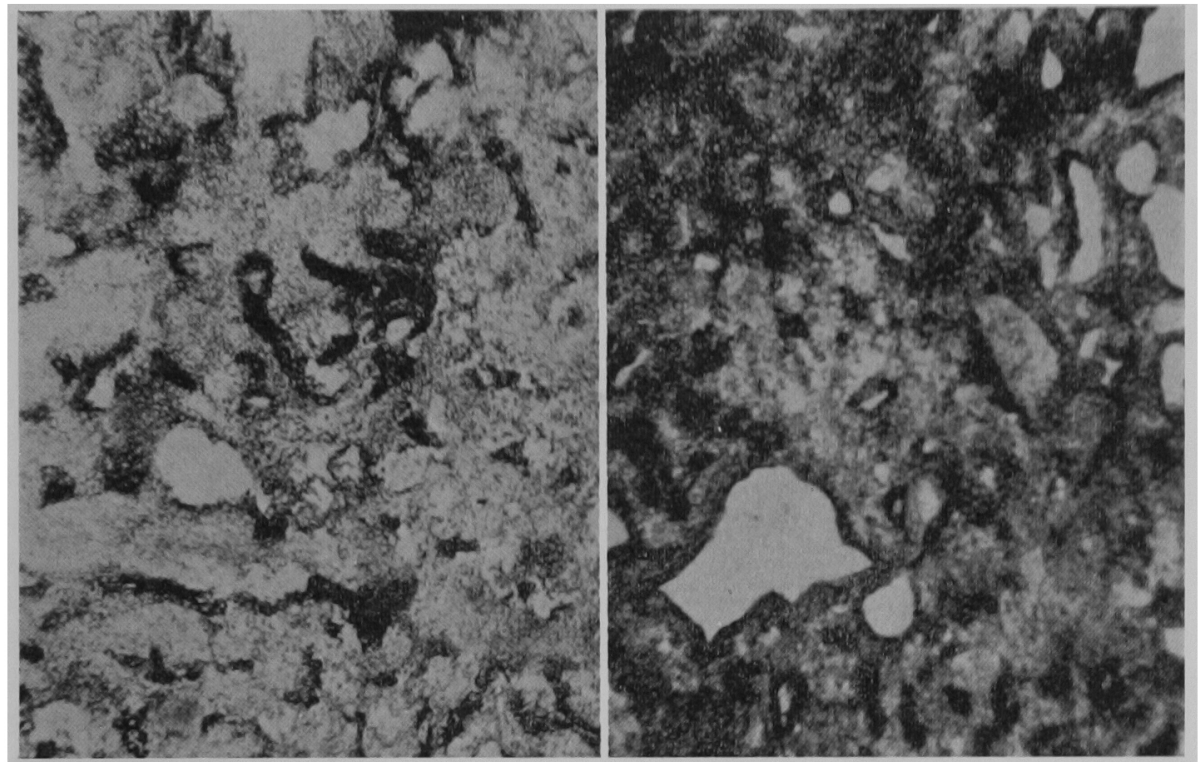

写直 17，18 (2193)

17. Succinate dehydrogenase

18. Lactate dehydrogenase $\times 100$

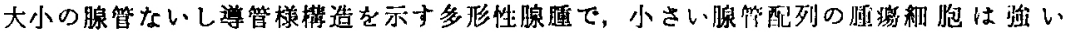

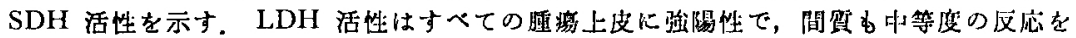
示す.

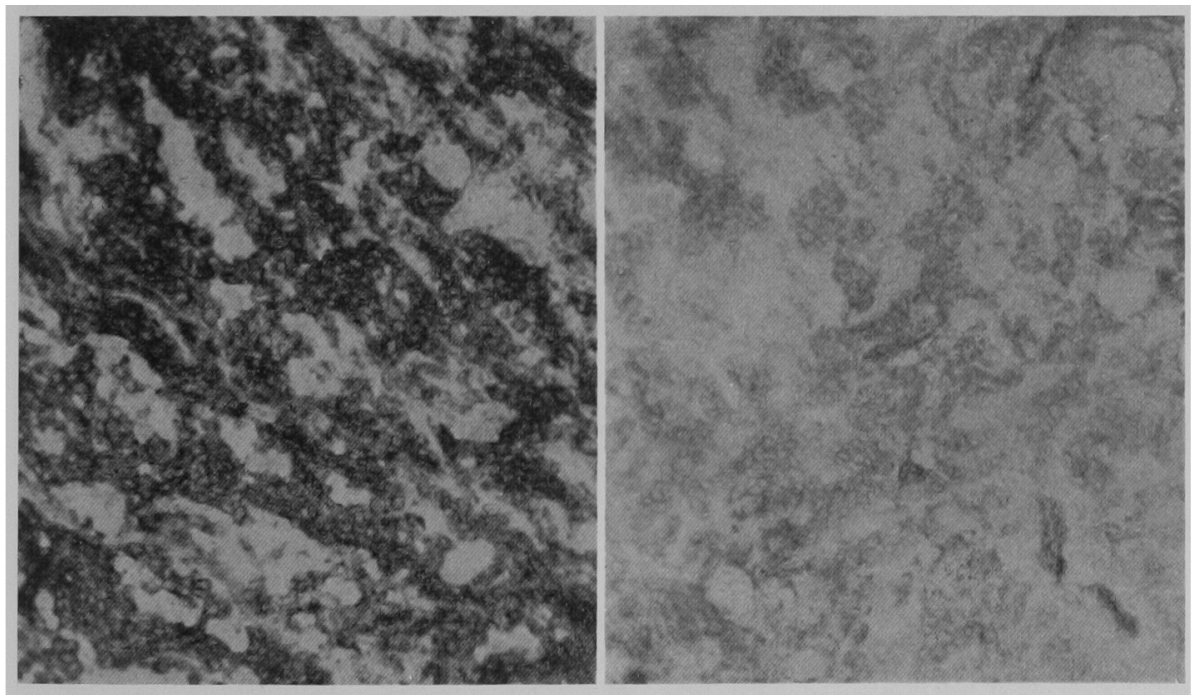

写真 19, 20 (1140 B)

19. Lactate dehydrogenase

20. Glucose-6-phosphate dehydrogenase $\times 100$

この形の腫焬初胞は全般的に強度の $\mathrm{LDH}$ 活性，低いG6 $\mathrm{PDH}$ 活性を示す.

3、 9). 尰場細胞における ACP 活性は非常に不規則て あり, 腺管構造に強く（写真 $5,11 ）$ 㵐漫性増殖細胞に 活性が低いか陰性である。たとえば充実性の腺腫に㧍い て腺管を形成する以外の潮漫性増殖細胞の ACP 活性は
著しく低く，腺管構造上皮のみに強い反応が認められて いる（写真 11），乳頭状腺腫の毛細血管之思われるるの に強陽性反応を認めるがこのよらな所見は稀なるのと いえる（写真 15），陌平上皮化成形のもので角化の著し 

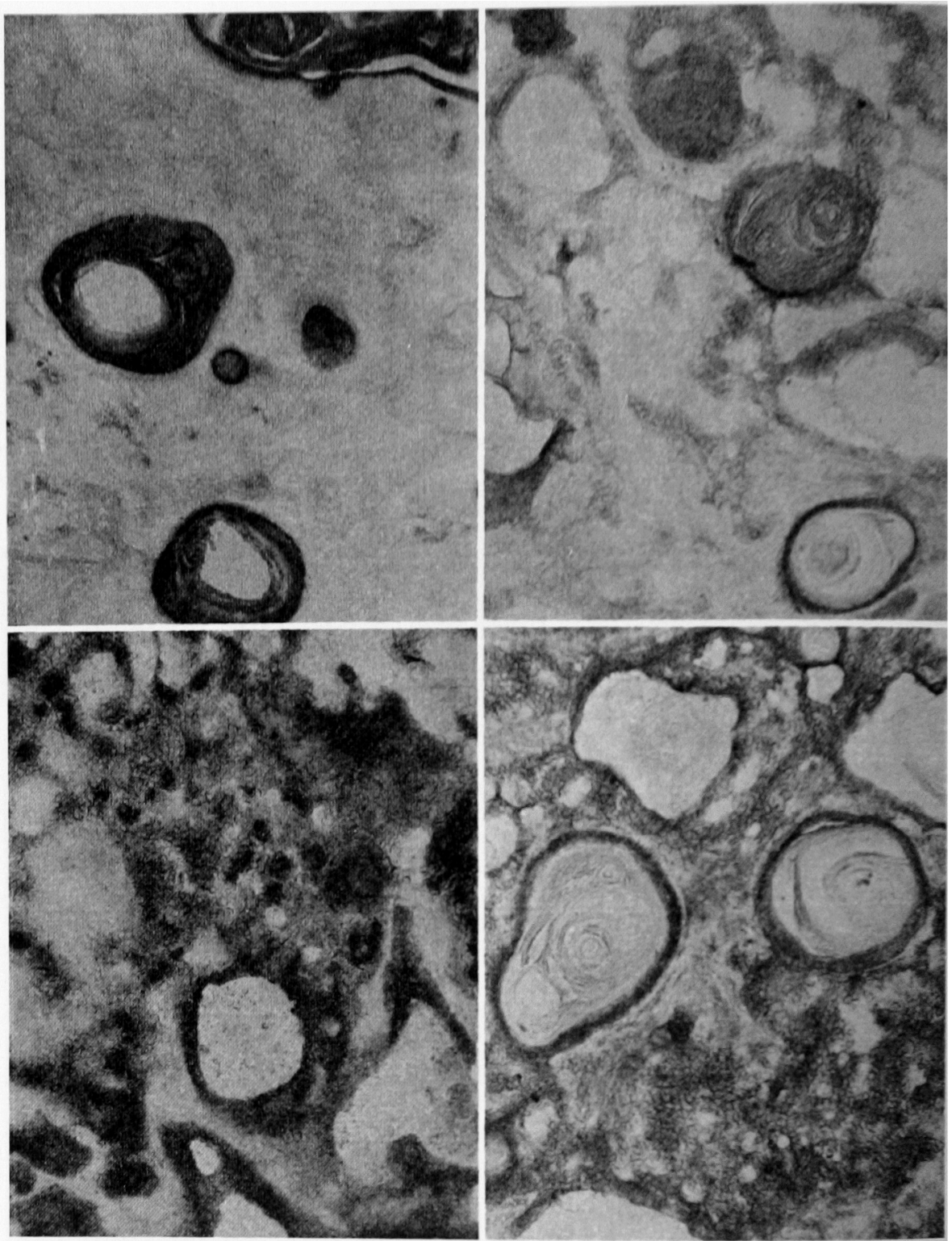

写兵 21，22，23，24 (779，1361)

21. Acid phosphatase

23. Lactate dehydrogenase
22. Succinate dehydrogenase

24. Glucose-6-phosphate dehydrogenase $\times 100$

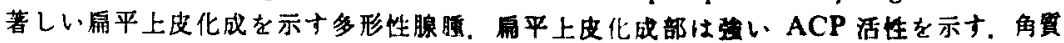

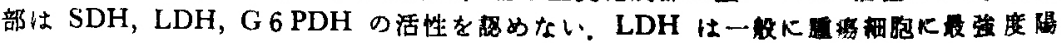
性, SDH 怟い活性，G6 PDH は中等の反俯を示才。

い部位は强い ACP 活性を示している（写直 21）。

3. Esterase (EST)

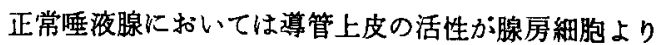
強い，腺組織間質の脂肪が強く染まることがある，小口 腔腺の活性は一般に低い，多形性腺腫においては充実形

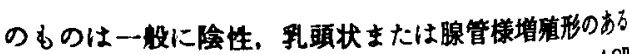

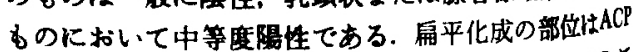

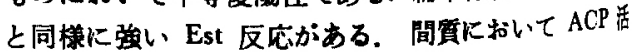
性陽性の组球は Est 活性を示すことがある。

4. $\beta$-Glucuronidase ( $\beta$-Gase) 
大唾液腺の $\beta$-Gase 活性は線条部を中心として強い染 色性を認め，腺房細胞の反応は中等度以下である，口腔 粘液腺は比較的強い活性を示す。腺腫においてはすべて の形のものの上皮細胞に中等度以上の $\beta$-Gase 活性を認 める、腺管系構造は襄胞形を除き強い活性を示し, 皮脂 腺形のるのは特に強く染まる。充実性のるので細胞が肉 腫様の部位の活性は弱い，間質は活性が低いか，または これを欠き，粘液腺様の部位は陰性である。

\section{Aminopeptidase (AMP)}

正常腺組織はそれ程強いAMP 活性を示さない， 口蓋 粘夜腺は強い AMP 活性を示すことがある，唾液腺多形 性腺腫に打いては AMPは原則的に腫瘍上皮に認められ ず,間質に著しい反応を示すことが多い.しかし少数例の 腺管形腺腫において腺管上皮細胞と間質に著しい AMP 活性を認める。間質の AMP 反応は一般に細胞浸潤に一 致して出現するけれども，高度の浸潤部位が必ずしも強 いAMP 活性を示すとは限らず，また必ずしも ALP 活 性と相関的関係を認めない。

6. Succinate dehydrogenase $(\mathrm{SDH})$

大唾液腺，小口腔腺ともに SDH の活性は導管系上皮 細胞に著しい，導管のうちで線条部の細胞が 最も高い $\mathrm{SDH}$ 活性を示す。漿液腺の細胞は粘液腺に比べ反応が 強い，多形性腺腫に拈いてはすべての形に括いて原則的 飞低いSDH 活性を認める（写真 16，17，22，25，26）.
特に充実性, 㵐漫性の構造においてはその腫瘍細胞の活 性は軽度である。充実形の腺腫において小腺管部に一致 して強いSDH の活性を認める（写真 17），腺管系の腺 腫において腺管上皮細胞の所々飞著しく高いSDH 活性
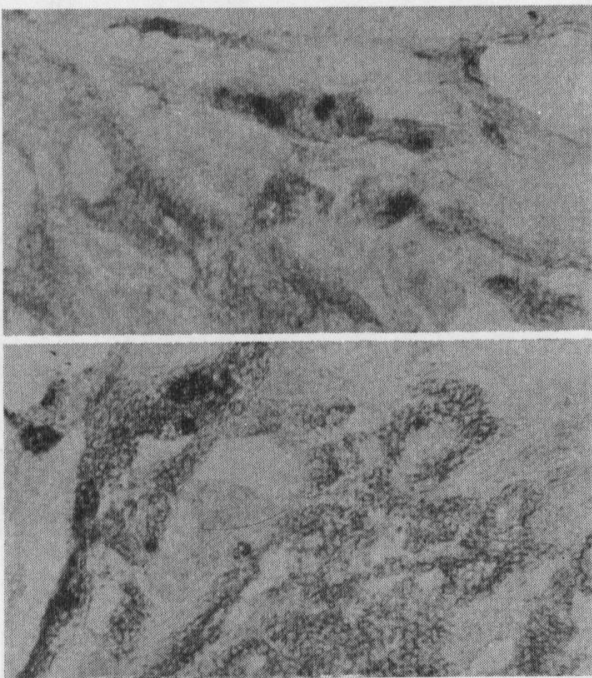

写真 25,26 (2145) Succinate dehydrogenase $\times 100$ 腫癔上皮の一部に極めて強い SDH 活性を示す 細胞 (oncocyte) がある.
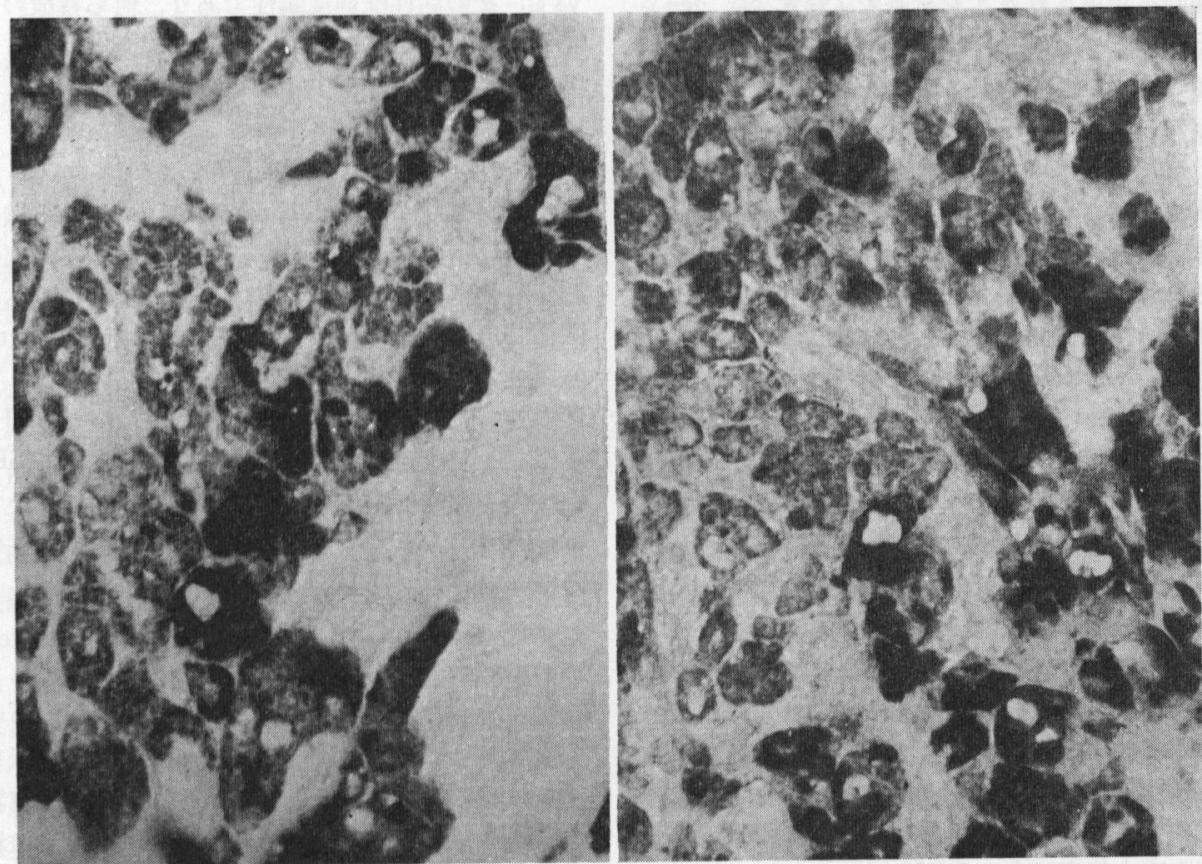

写真 27, 28 (2145)

27. Succinate dehydrogenase

28. Lactate dehydrogenase $\times 100$

多形性腺腫中の好酸性稩胞。好酸性細胞は強い SDH, LDH 活性を示す特徵がある。 


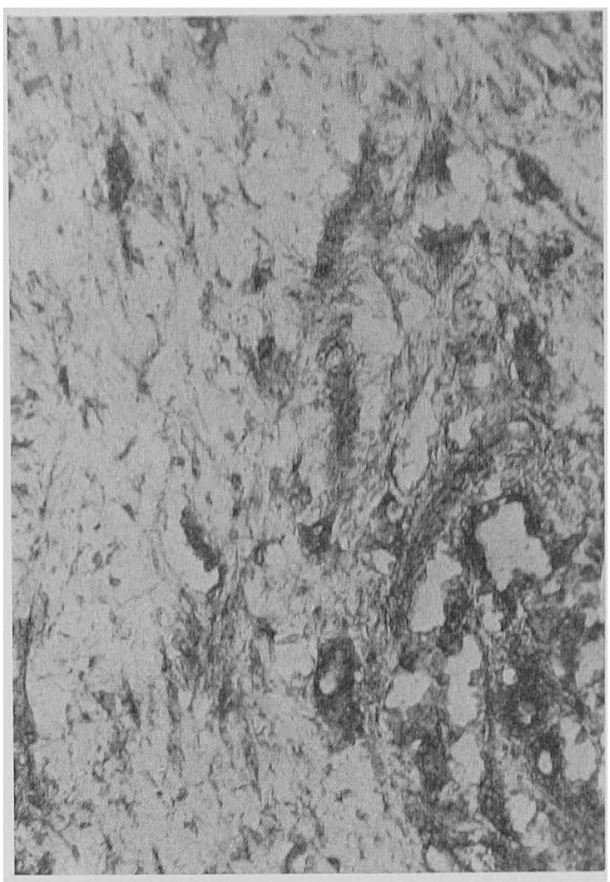

写真 $29(999,1401)$ Lactate dehydrogenase $\times 100$ 硝子㴍恋性部の $\mathrm{LDH}$ 活性

を持った練胞が㤎められることがある（写真 25，26）。 立実形または腺管形の多形性㸡嗹のなかには，泊分的に 非常に強度の $\mathrm{SDH}$ 活性を保った䊶胞が存仕している。

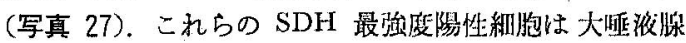
の線条部上皮，または小口腔腺の管上管上細胞の $\mathrm{SDH}$ 活件に類似して和り，腺腄の oncocytic changed cell （好酸性腺腫細胞）と考光られる。㦿平上皮化成部にお いて，角化の著明な部位は SDH 陰性である。間留はそ の活性が低く，特筑すべき所見を認めない.

7. Lactate dehydrogenase (LDH) および malate dehydrogenase $(\mathrm{MDH})$

すぺての唩液腺の腺房細胞，導管上皮細胞ともに强い 反応を示す. しかし導管上皮の SDH の染色性の方が LDH, MDH の染色性より強い，あらゆる組織形の多形 性腺腫は強い $\mathrm{LDH}$ 活性を示すのを原則としている(写 真 $7,12,18,19,23,28,29$ ). 特に充㷂形のbのに

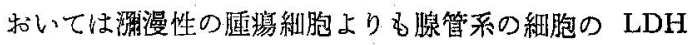
活性が高い（写真 12，18）。雇平上皮化成のbのにおい て角化梁周囲の連隍細胞は强い LDH の染色性を垫める (写真 23). 好酸性の尰瘍細胞は著しい $\mathrm{SDH}$ 活性とと むに最強度の LDH 反応が認められる（写真 28）。間犋 の線維性細胞は中等度以上の $\mathrm{LDH}$ 活性を示すが, 硝子 様問質において子線維成分は明らかな LDH 活性がある (写真 29). 粘液腫様間質は染まらない. 多形性腺腫に 和ける MDH の分布とその活性は LDH のそれらに似
てい\%.

8. (ilucose-6-phospliate deliydrogenase ( 6 6 PDH)

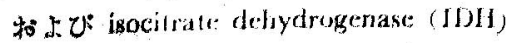

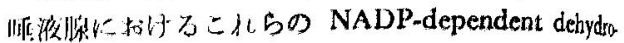

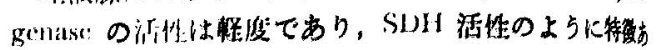

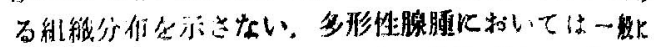

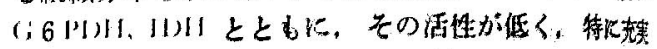

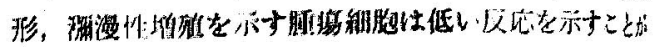

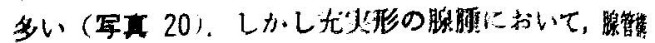

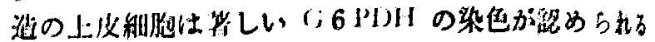

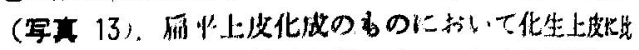

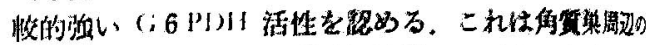

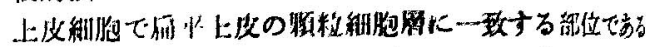

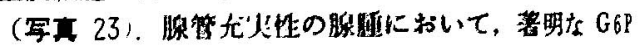

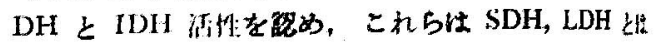

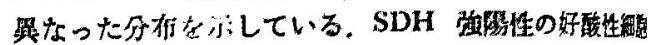

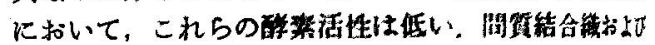

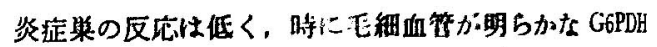

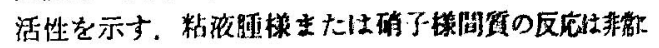
低いか，險性である。

9. Monoamine oxidase (MAO)

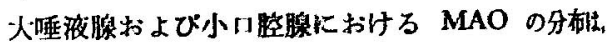

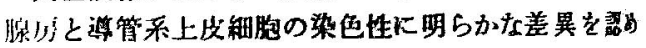

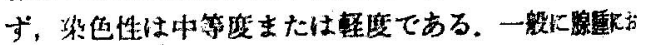

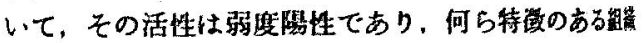

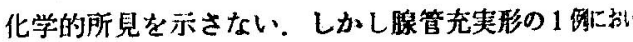

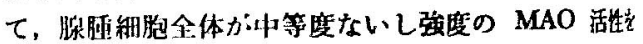
㢮めた。

10. Cytohirome oxidase

唾液腺における cylochrome oxidase の組辕化学的分 们は SDHのそれに一致する。すなわち線条部の上㢰 胞が最強度の活性を示している、これは糸粒体の分柿

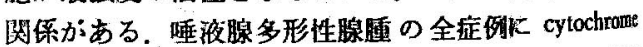
oxidase の染色を夷施しなかったか，主として SDH落 性の强い腫㷎について行った。このなかて SDH 活生の 著明な好酸栍腺腫と考えられる症例において SDH 反店 と cytochrome oxidase は分布と活性度において一形 る. 充实形, 㙞管系等の腺腫細胞は SDH 活性の強弱 同様に本酵秦反応子出現する.

\section{考察}

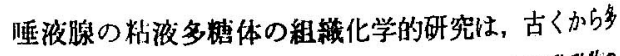
くの吥究艺により報告されている。.人または哺乳動物の 大極液腺の醉慗組織化学的研究はかなり報告されてい尚 $\not^{4} 4,7,9 \sim 11,13,22,28 \sim 31,33,34,36,69,76,77$ ，小口腔腺の報告は活 んど認められない，人または哺乳動物の唾液腺に打当

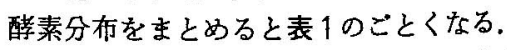

この表 1 は水解䤃素と酸化醉素の分布をまとめたのの 


\begin{tabular}{|c|c|c|c|c|c|c|c|c|c|}
\hline & \multicolumn{4}{|c|}{ Acini } & \multirow{2}{*}{$\begin{array}{c}\text { Myo } \\
\text { epithelium }\end{array}$} & \multicolumn{4}{|c|}{ Ducts } \\
\hline & \multicolumn{2}{|c|}{ Serous cells } & \multicolumn{2}{|c|}{ Mucous cells } & & \multicolumn{2}{|c|}{ Striated duct } & \multicolumn{2}{|c|}{ Secretory duct } \\
\hline Alkaline phosphatase & \multicolumn{2}{|c|}{0} & \multicolumn{2}{|c|}{0} & +4 & \multicolumn{2}{|c|}{0} & \multicolumn{2}{|c|}{0} \\
\hline Acid phosphatase & +1 & +3 & \multicolumn{2}{|c|}{+1} & $?$ & +1 & +2 & +1 & +2 \\
\hline Non-specific esterase & +1 & +2 & +1 & +2 & $?$ & \multicolumn{2}{|c|}{+1} & \multicolumn{2}{|c|}{+1} \\
\hline$\beta$-glucuronidasc & +1 & +3 & +1 & +2 & $?$ & \multicolumn{2}{|c|}{+2} & \multicolumn{2}{|c|}{+1} \\
\hline Aminopeptidase & \pm & +2 & & \pm & 0 & \multicolumn{2}{|c|}{+2} & +1 & +2 \\
\hline Succinate dehydrogenase & +1 & +2 & \multicolumn{2}{|c|}{+1} & $?$ & \multicolumn{2}{|c|}{+4} & +1 & +2 \\
\hline Cytochrome oxidase & +1 & +2 & \multicolumn{2}{|c|}{+1} & $?$ & \multicolumn{2}{|c|}{+4} & +1 & +2 \\
\hline Lactate dehydrogenase & \multicolumn{2}{|c|}{+2} & +1 & +2 & +1 & \multicolumn{2}{|c|}{+3} & +2 & +3 \\
\hline Glucose-6-phosphate dehydrogenase & \pm & +1 & \pm & +1 & $?$ & +1 & +2 & \multicolumn{2}{|c|}{+1} \\
\hline Mono-amine oxidase & \multicolumn{2}{|c|}{+1} & \multicolumn{2}{|c|}{ \pm} & $?$ & +1 & +2 & & \\
\hline
\end{tabular}

であり，特徴的な所見は ALP が腺房紐胞基底部にある 筋上皮細胞 ${ }^{4,30,36,39,67)}$ と毛細血管壁にのみ強陽性で，ま た系粒体酵素が線条部を中心とした導管系上皮紐胞に著 しく強い活性を示すことである22, 30,31,33,76,77).

\section{多形性腺腫における酵素の組織化学}

Alkaline phosphatase (ALP) 本醅素は正常唾液腺に おいてはすでにのべた筋上皮緗胞にのみ分布4,30,36,67) し， 他の腺細胞には含まれない本酵素は一般に炎症病舁, 結合織や骨の再生時に強い活性が出現する。上皮性腫痬 において ALP 活性は多種類の腫湯には出現せず, 乳腺 の腺腫または線維腺腫, 乳癌のあるものに比較的出現率 が高く他の腺癌, 扁平上皮癌においては陰性のことが多 、53,61,70)，今まてに報告された唾液腺由来の腫瘍組織に おいて ALP 活性はすべて陰性である6,27,38,41,55,60,61). 腫煌組織における ALP 活性は間質結合織に認められ, これは炎症性反応と比例的な関係にある $25,32,40,46)$. 唾淮 腺の多形性腺腫において, ALP 活性は一般に尰瘍上皮 に陰性であるが少数の症例において陽性反応が認められ たが，唾液腺良性腫瘍細胞に㧍ける ALP 活性は一般的 にみて陰性の症例が大部分を占めているものといえよ 万。笳上皮細胞は强いALP 活性を示与が、これから出 現したと考えられる筋上皮腫または筋上皮腺腫はそれ程 強いALP の活性を示さないといわれ，またこの方面の 電子顕微鏡的組織化学的研究がある ${ }^{13,39)}$.

Acid phosphatase (ACP) と $\beta$-glucuronidase $(\beta-G)$. 両酵素はライゾソーム醉素であり，一般に腺分泌細胞の 退行性変化等に関係して出現するといわれ ${ }^{37,45)}$ 人の腫沮 細胞に怙ける ACP 活性は不特定かつ不規則な分布を示 すといわれている14,17,37,45,65)。 また一般に皮虞，粘膜上 皮の角化現象と関係が深いことが報告されている. 本腫 㻛の扁平上皮化成した高度角化部位は $\mathrm{ACP}$ 活性が強い。 腺組織由来の隀瘍において過度の解化部におけるこれら の酵素の分布は届平上皮や扁平上皮癌のそれと一致する ものである ${ }^{32,57)}$ ，多形性腺腫において間質の組織球が木
酵素陽性であったのはライゾソームの存在が考えられ る.

Non-specific esterase. 腫瘍の esterase ${ }^{18)}$ の酵素組織化 学的研究は比較的少なく ${ }^{12}$, 唾液腺腫㕫における esterase の組織化学的報告はほとんどみたらない11). 唾液腺の esterase は導管系上皮に存在することが認められている が，一般にこの酵素は消化管上皮や乳腺，甲状腺に強い 反応が存在する。また胃, 腸, 朋, 乳腺, 卵栄等の良 性または悪性腫瘍に軽度ないし高度の反応が認められ $ろ^{53)}$. 皮店口腔食道粘膜等の扁平上皮において esterase は基底細胞層から顆粒度まで存在することが知られてい る。多形性腺腫の扁平上皮化成部に ACP と同様に強い esterase の活性が垫められたが、これはこの部位が正常 な扁平上皮と類似の性質を借えたものと考えられる。唾 液腺腫瘍の間質において組織球が ACP 活性と同様に esterase 反応を示したが、腫瘴間質の esterase について は, 成熟した組織球は強い活性，線維芽細胞は少し弱い 活性，形質紏胞は種々の程度の酵素反応を示すといら報 告がある47)。

Aminopeptidase (AMP)。腫瘍における本醳素の意義

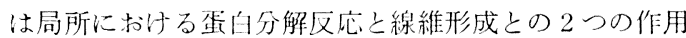
を持つものと理解されている $5,8,16,43,59,61,62)$. 蛋白分解

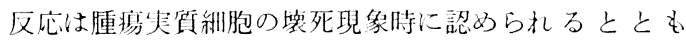

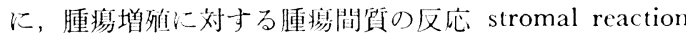
として出現与るものと考守られている。他方線維形成な らびに組織の修復再生と阙原して AMP が出現するが， この現象は骨折，㓣偒治撩等に占いて認められている。

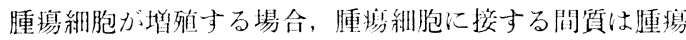
の增殖に抵抗して線維形成之同時に局所の蛋白分解現象 も出現するものと考えられる。このいわゆる間钼反応に ついては腫㿑の周囲間質と腫序間間質と比較与る場合, その反応の性格と意義に差異が梁められる ${ }^{62)}$ 。一般に良 性腫瘍に打いては，周囲間質は腫瘍細胞の昖大性增殖に 対して結合織性の被膜形成として出現し，覀性腫疹に拉 
いては腫瘍細胞の浸潤性増殖に対して破壊性の変化すな わち蛋白分解現象としてとらえられる. Braun-Falco 等5) はこの腫瘍増殖に対する間質反応を悪性腫瘍の特質と考 えている．腫瘍間間質反応における退行性変化は良性腫 瘍, 悪性腫瘍ともに何らかの形として認められる共通所 見であるが，必ずしも多くの例に AMP 活性が出現する とは限らない.一般に腫瘍間間質反応はそこに存在する 炎症反応之, 腫瘍増殖に伴ら栄養障害等に起因する受身 的の変化があげられる．前者の例として強いALP 活性 と AMP 活性の出現があり，この両酵素反応は同時に同 一部位へ出現するのが通常に認められる組織化学的所見 である，唾液腺多形性腺腫に拈いてこれらの所見が認め られたが，間質の myxomtous または hyalinous な部位 には何れの酵素活性も出現しなかった.

上皮性の腫瘍または病変で AMP の出現するものに, 胃の腸上皮化成, 乳腺の腺腫があげられる。唾液腺の上 皮性腫瘍における AMP 活性についてはあまり報告がな く，比較検討できる資料がとぼしいが，多形性腺腫の腫 瘍上皮細胞に本酵素の強い活性が認められたことは興味 がある，正常唾液腺に括いては, 腺細胞, 導管系細胞と もにそれ程強い AMP の活性を示さないが28)，特定症例 の腫瘍上皮に強い活性が出現したことは今後他の腫瘍と 比較検討する必要があろう。

唾液腺に括ける $\mathrm{SDH}^{30,31,66,76,77)}$ や cytochrome oxidase $^{22,23)}$ のごとき系粒体酵素は線条部を主とした導管系 上皮細胞に存在する特徵がある. 多くの種類の唾液腺腫 瘍の5ち Oncocytoma または好酸性細胞腫および Warthin 氏腫瘍 (papillary cystadenoma lymphomatosum) は正常な唾液腺の線条部と同様に著しい SDH と cytochrome oxidase の活性が認められる特徵がある ${ }^{1,2,15,19,}$ ${ }^{20,21,68)}$. 唾液腺の腫湯や老人の正常唾液腺の細胞の一部 には好酸性の oncocyte が混入していることはすでに のべた ${ }^{63)}$. 最近の電子顕微鏡的観察によると唾液腺の oncocyte には多くの糸粒体の存在を認め ${ }^{72,73)}$, 著しい $\mathrm{SDH}$ 活性は糸粒体に原因していることが確認された ${ }^{24}$ ， 26). 好酸性の oncocyte は唾液腺以外に, 甲状腺に認め られるものを Askanazy cell ${ }^{23,75)}$ 上皮小体のものをWelsh cell と呼び1,74), これらの細胞も著しく高い SDH 活性 を示す。これらの細胞は Hamperl のいらいわゆる oncocyte 群に入るものと考えられる1,2,15,19). しかし何故 oncocyteに系粒体が多量に存在するかは明らかでない.

エナメル上皮腫において稀に好酸性の顆粒細胞が認め られることがあり，これを顆粒細胞性エナメル上皮腫 granular cell ameloblastoma と称えているが, この顆粒。 細胞は ACP $\beta$-Gare 等のライゾソーム酵素群の活性が 高く, 酸化酵素の活性が低い.エナメル上皮腫の顆粒細 胞はある種の退行性変化の結果出現したもので, 唾液腺 またはこの腫瘍中に出現する oncocyte とは生物学的性 格を異にしている58).
一般に腫痬細胞における SDH 活性は低下し, LDH 活 性は増強されることが知られているが44,49,52,5?,70), 唾液 腺の多形性腺腫においても大体この原則が適応される. 唾液腺多形性腺腫においては組織形態の項目で詳述した ごとく腫瘍細胞の形態と配列ならびに間質の性質等によ り同一腫瘍組織においても部位により脱水素酵素の反応 が異なることが多い。この所見は腫瘍細胞の分裂増殖が 部位により異なるためと考えられ，特に大きい腫瘍の中 央病巣はしばしば壊死等の退行変性に括ちいり，この場 合脱水素酵素反応は減弱または著しく低下しているが, 周囲の増殖しつつある腫瘍細胞は明らかな反応を示す. 正常な唾液腺の $\mathrm{SDH}$ 活性と腫瘍細胞のそれを比較する 場合, 前述の oncocyte を除いて, すべての多形性腺腫 の細胞は唾液腺導管の最強度反応より著しく減弱してい る. 唾液腺の腫瘍発生に関して導管系上皮細胞が組織由 来であろらという説があるが, 酵素組織化学的にみて, はとんどの唾液腺腫瘍は正常腺組織の線条部に類似した 所見をとらない.

腫瘍細胞における NADP-dependent な脱水素酵素, たとえば G 6 PDH や IDH は腫瘍細胞の増殖の著しい 場合増強されるか（悪性の示標）, またはステロイド分 泌機構と関係して出現する ${ }^{35,44,50,51,53,54,56,64,70,71,78)}$. た とえばステロイド分泌組織である卵巣の汇胞と黄体 ${ }^{35,54}$, ${ }^{64,71,78)}$, 精巣の間質細胞 ${ }^{54)}$, 副腎皮質 ${ }^{54)}$ 等は強い G $6 \mathrm{P}$ DH 活性があり，これらから発生したいわゆる functioning tumors も強い酵素活性を示す。しかし唾液腺の 良性の多形性腺腫においては，NADP-dependentな脱水 素酵素の反応は弱く特徵ある分布や活性は示さなかっ た.

唾液腺の腫瘍の一部が著しく扁平上皮化成を示す症例 がある.この場合の酵素パターンは正常な扁平上皮に類 似していることはすでにのべた。一般に重層扁平上皮に 扣ける脱水素酵素の組織化学的分布は 3 つのパターンに 大きく分けられる ${ }^{48,57)}$. すなわち基底細胞に存在する $\mathrm{SDH}$ 活性, 角質層を除く全層に分布する LDH および $\mathrm{MDH}$ また，角化傾向の強くなると出現する G $6 \mathrm{PDH}$ の分布で，これらの上皮各層に拈ける酵素の分布形式 は,この腫瘍の扁平上皮化成部においても同様に認めら れた。

\section{結論}

唾液腺の多形性腺腫 pleomorphic adenoma（以下腫 瘍と記載する）34例について酵素の組織化学的所見につ き以下の結論を得た. 多形性腺腫は部位により組織学的 構造が著しく異なるため, この所見の記載は特殊な構造 または細胞は除き一般的の病理学的所見に対する酵素組 織化学的の成績とした.

1. Alkaline phosphatase は大部分の腫瘍組織におい 
て, 上皮性細胞に陰性，間筫の線維成分浸潤細胞，毛 細血管堲に陽性である。一部の限られた症例において は腫淳上皮に陽性のことがある。

Acid phosphatase $と \beta$-glucuronidase は嗹暍上皮に 中等度の反応を示し，間質の組織脙江強陽性である。

Esterase は腫疹細胞に強い活性を示す症例はなく， 間質の組織球が強陽性のことがある。

Aminopeptidase は大部分の症例の腫痀細胞は陰性 か弱陽性であるが，少数例において強い活性が㟫管梯 構造に出現していた。間質においては一般に淂性で， Alkaline phosphatase と相関的関係が存在した.

Succinate dehydrogenase $\downarrow$ cytochrome oxidase は大部分の腫㾨細胞に弱陽性である。好酸性細胞 (oncocyte) は著しく高い本酵辢活性を示し，その活 性は正常唾液腺の線条部に類似している。

Lactate dehydrogenase (LDH) は一般に董瘍細胞 に強い活性を示し間質の線䊒成分も比較的強い本酵素 反応を示す。 Malate dehydrogenase の活性と分布は LDH に類似していた。これらの染色性は正常な锃液 腺に比べ同様かわずかに強い程度であった。

Glucose-6-phosphate dehydrogenase は一般に腫痬 細胞に弱い活性を示し，強い反応を示した症例はなか った，間質の細胞成分も著しい反応は示さず，毛細血 管壁が陽性のことがある. Isocitoate dehydrogenase はG 6 PDH とよく類似した分布を示すが，染色性は さらに低かった。

Monoamine oxidase は大部分の症例に弱い反応を 示した. 腫場上皮細胞における染色性は正常な喠液腺 の腺房細胞よりも低下していた。

多形性腺腫の間質において, 粘液腫様变性部位 myxomatous 扰よび硝子様变性部位 hyalinous は水解 醭素も眖木素醭素の活性も認められない。

本論文の要旨は第31回日本癌学会総会 (名古屋) 昭和47年10月において発表した。

本研究費の一部は文部省科学研究癌特別研究費に よった。

本研究を長期にわたり御指導頂いた大阪大学菌学 部川勝䁂作教授拉よび岐阜菌科大学口腔外科第 1 满 座森昌彦氏に感謝の意を表します。

\section{文献}

1) Balogh, K. Jr., Cohen, R.B.: Oxidtive enzymes in the epithelial cells of normal and pathological human parathyroid glands, A histochemical study, Lab. Invest., 10: 345, 1961.

2) Balogh, K.Jr., Roth, S.I.: Histochemical and electron microscopic studies of eosinophilic granular cells (oncocytes) in tumors of the parotid gland, Lab. Invest., 14: 310, 1965.

3) Barka, T., Anderson, P.J.: Histochemistry,
Theory, Practice and Bibliography, Hoeber Med. Div., 1963.

4) Bogart, B.I.: The fine structural localization of alkaline and acid phosphatase activity in the rat submandibular gland, J. Histochem. Cytochem., 16: 572, 1968.

5) Braun-Falco, O.: Histochemische Aminopeptidase Darstellung in normaler Haut, bei Psoriasis, Dermatitis, Basaliom. Spinozellularen karzinom und Mollusum sebaceum, Derm. Wschrf., 134: 1341, 1959.

6) Bruce, B. A., Wertheimer, F.W.: Enzyme histochemistry of adenoid cystic carcinoma of minor salivary glands, 25: 30, 1967.

7) Burstone, M.S.: Esterase of the salivary glands. J. Histochem. Cytochem., 4: 130, 1956.

8) Burstone, M.S.: Histochemical demonstration of proteolytic activity in human neoplasms, J. Nat. Cancer Inst., 16: 1149, 1956.

9) Chauncey, H.H., Quintarelli, G.: Histochemical localization of hydrolytic enzymes in human salivary glands, J. dent. Res., 38: 961, 1959.

10) Chauncey, H.H., Quintarelli, G.: Localization of acid phosphatase, nonspecific esterase, and $\beta$-D-glucuronidase in parotid and submaillary glands of domestic and laboratory animals, Am. J. Anat., 108: 263, 1961.

11) Chauncy, H.H, Shklar, G., Brooks, R.: Histochemistry of human salivary gland tumors, Oral Surg. Oral Med. Oral Path., 15: '950, 1962.

12) Cohen, R.B., Nachlas, M.M., Seligman, A. M:. Histochemical demonstration of esterase in malignant tumors, Cancer Res., 11: 709, 1951.

13) Cutler, L., Chaudhry, A.P., Montes, M.: Alkaline phosphatase activity associated with the neuclear pore in normal and neoplastic salivary gland tissue, J. Histochem. Cytochem., 22: 1113, 1974.

14) Fishman, W.H., Baker, J.R., Borges, R.F.: Localization of $\beta$-glucuronidase in some human tumors, Cancer, 12: 240, 1959.

15) Fisher, R.: Uber den histochemischen Nachweis oxydativer Enzyme in Onkocyten Verschiedener Oregane, Virchows Arch Path. Anat., 334: 445, 1961.

16) Glenner, G.G., Burstone, M.S., Meyer, D.B.: A study of aminopeptidase activity in the stroma of neoplastic tissue with comparison of histochemical techniques, J. Nat. Cancer Inst., 23: 857, 1959.

17) Gomori, G.: Distribution of acid phosphatase in tissue under normal and under pathologic 
conditions, Arch. Path., 32: 189, 1941.

18) Gomori, G.: Histochemistry of human cestl-rases, J. Histochem. (ytochem., 3: 479, 1955.

19) Hamperl, H.: Oncocyles and so-called Hürtlıle. cell tumor, Arch Path., 49: 563, 1950.

20) Hamperl, H.: Onkocyten und Onkocytome, Virchow Arch Path. Anat., 335: 452, 1962.

21) Hamperl, H.: Onkocytome der Seicheldrusen. Z. Krebsforsch, 64: 427, 1962.

22) Hannibal, M.J., Nachlas, M.M., Scligman, A.M.: Histochemical localization of cytochrome oxidase in human tissues and neoplasms, Cancer, 13: 1008, 1960.

23) Heimann, P., Lijunggren, J.G., Lowhagen, T., Hijern, B.: Oxyphilic adenoma of the human thyroid, Cancer, 31: 246, 1973.

24) Hubner, G., Klein, H.J., Sehummelfeder, N.: Zur Ultrastruktur der Onkocytome, Klin. Wochensch, 43: 798, 1965.

25) Kabat, K., Furth, J.: A histochemical study of the distribution of alkaline phosphatase in various normal and neoplastic tissues, Am. J. Path., 17: 303, 1941.

26) Kay, S., Still, W.J.S.: Flectron microscopic observations on a parotid onycocytoma, Arch Path., 96: 186, 1973.

27) Kaufmann, F., Stiebitz, R.: Zur Enzymhistochemie solider und tubularer Basalzelladenoma der Speicheldrusen, Deut Zahn-Mund Kiferheil, 52: 237, 1969.

28) Kawakatsu, K., Mori, M., Mizushima, T., Murakami, M.: Histochemical observations on aminopeptidase activity in normal salivary gland, Arch. hist. jap., 19: 509, 1960.

29) Kawakatsu, K., Mori, M., Fukuda, K., Deguchi, S.: Histochemical studies of normal salivary glands. VI. Distribution and localization of $\beta$-glucuronidase, $\beta$-galactosidase, and $\beta$-glucosidase in the major salivary glands of experimental animals, Arch hist. jap., 19: 533, 1962.

30) Kawakatsu, K., Mori, M.: Histochemical study of enzyme patterns in the hunian submaxillary gland, Histochemie, 2: 293, 1962.

31) Kawakatsu, K., Mori, M., Mizushima, T., Koizumi, K.. Histochemical studies of salivary glands, IX. Histochemical localization of succinic dehydrogenase and triphosphopyridine nucleotide diaphorase activity, Z. Zellforsch, 56: 641, 1962.

32) Kawakatsu, K., Mori, M.. Histochemical evaluation of enzymatic activities in human squamous cell cancer, Cancer Res., 23: 539, 1963.

33) Kawakatsu, K., Mori, M., Mizushima, T.,
Makino, H.. Histochemical demonstration of oxidative enzymes in human alivary galnds, Arch hisl. jap., 24: 247, 1964.

34) Kawakatsu, K., Mori, M., Mizushima, T, Makino, H.: Histochemical localization of cylochrome oxidase in salivary glands, Arch hist. jap., 24: 427, 1964.

35) Koudstaal, J., Bossenbrock, B., Hardonk, M. $\mathrm{J}$.: Ovarian tumors investigated by histoche. mical and enzyme histochemical methods, Am. J. Olnstet. Gynecol., 102: 1004, 1968.

36) Licson, C.R.: Localization of alkaline phosphatase in the submaxillary gland of the rat, Nature, 178: 858, 1956.

37) L.mon, H.M., Davison, M.M., Asimov, I.: Acid phosphatase activity in normal and neoplastic human tissur, Cancer, 7: 92, 1954

38) Lim, D.J., Mori, M.: Enzyme histochemical observations of adenoid cystic carainoma "A report of 4 cases and their histochemical findings" Ann. histochem., 14: 299, 1969.

39) Luna, M.A., Mackay, B., Gamez-Araujo J.: Myoepithelioma of the palate, Report of a case with histochemical and electron micros copic, observations, ('ancer, 32: 1429, 1973.

40) Manheimer, L.H., Seligman, A.M.: Improve ment in the method for the histochemial demonstration of alkaline phosphatase and its use in a study of normal and neoplastic tiewex, J. Nat. Cancer Inst., 9: 181, 1948.

41) Matsumura, T.: Enzyme histochemistry of experimentally induced tumors in the mouse submaxillary and subligual glands during carcinogenesis, Gann., 57: 251, 1966.

42) Mira, E., Vidi, I.: A histochemical study on the histogenesis of the mixed tumors of the human salivary glands, Acta. histochem., 36 : 389, 1970.

43) Monis, B., Nachlas, M.M., Seligman, A.M.: Study of leucine aninopeptidase in neoplastic and inflammatory tissues with a new histochemical method, Cancer, 12: 601, 1959.

44) Monis, B., Nachlas, M.M., Seligman, A.M.: Histochemical study of 3 dehydrogenase systenis in human tumors, Cancer, 12: 1238,

45) Monis, B., Banks, B.M., Rutenburg, A.M.: $\beta$-Glucuronidase activity in malignant neoplasms of man; a histochemical study, Cancer, 13: $386,1960$.

46) Monis, B., Rutenburg, A.M.: Alkaline phosphatase activity in neoplastic and inflammatory tissues of man, Cancer, 13: 538, 1960.

47) Monis, B., Weinberg, T.: Cytochemical study of esterase activity of human neoplasms and stroma macrophages, Cancer, 14: 369, 1961. 
48) Mori, M., Mizushima, T., Koizumi, K.: A comparative histochemical evaluation of various dehydrogenases in the oral squamous epithelium, Histochemie, 3: 111, 1962.

49) Mori, M., Mizushima, T., Oka, R., Okamoto, Y., Takita, Y.: Histochemical observations of succinic, malic and lactic dehydrogenases in oral tumors, Oral Surg. Oral Med. Oral Path., 17: 352, 1963.

50) Mori, M., Sugimura, M., Matsumura, T., Kawashima, H.: Histochemical study on the localization of glucose-6-phosphate dehydrogenase in human tumors, Gann., 54: 433, 1963.

51) Mori, M., Matsumura, T., Sugimura, M. Kawashima, H.: Histochemical study on the localization of isocitric dehydrogenase in human tumors, Gann, 55: 117, 1964.

52) Mori, M., Yoshikawa, K., Matsumura, T., Fukui, A., Kawakatsu, K.: Histochemical studies of oxidative enzymes in human oral tumors, J. Osaka Univ. Dent. Sch., 4: 17, 1964.

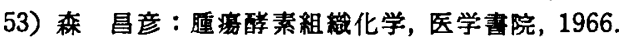

54) Mori, M.: Histochemical evaluation of NADPdependent glucose-6-phosphate and isocitrate dehydrogenases in steroid producing organs and tumors, Arch. hist. jap., 28: 45, 1967.

55) Mori, M., Yoshimura, Y., Morimoto, Y., Kawamoto, T.: Histochemical observation of adenocarcinoma in the oral cavity, Brit. J. Oral Surg., 5: 230, 1968.

56) Mori M., Morishita, M., Matsuura, H.: Histochemical observations of NADP-linked glucose-6-phosphate and isocitric dehydrogenases in human neoplasia, Acta. histochem. Cytochem., 1: 154, 1968.

57) Mori, M.: Methods for the early diagnois of oral tumors, Histochemistry, Int. dent. J., 18: 724, 1968.

58) Mori, M.: Histochemical evaluation of enzymes in ameloblastic tumors Acanthomatous and granular-cell ameloblastoma, J. Oral Surg., 28: 825, 1970.

59) Mottet, N.K.: Histochemical observations on the role of stromal aminopeptidase activity following neoplastic cell invasion, Am. J. Path., 39: 17, 1961.

60) Murata, I., Miyaji, T.: Histochemical evaluation of enzymatic activities in pleomosphic salivary adenoma, Oral Surg. Oral Med. Oral Path., 22: 82, 1966.

61) Murata, I., Kawashima, A., Mori, M.: Histochemical study on alkaline phosphatase activity in human neoplasms, Gann, 57: 513,
1966.

62) Okamoto, Y.: Stromal response in relation to invading forms of tumors: A histochemical and histopathological study, Gann, 57: 563, 1966.

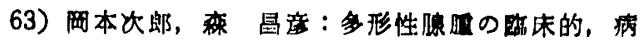
理学的矿宛, 日口外誌。

64) Pfleiderer, A. Jr., Teufel, G.: Incidence and histochemical investigation of enzymatically active cells in stroma of ovarian tumors, Am. J. Obsetet. Gynecol., 102: 997, 1968.

65) Reiner, L., Rutenburg, A.M., Seligman, A. M.: Acid phosphatase activity in human neoplasm, Cancer, 10: 563, 1957.

66) Rutenburg, A.M., Gofstein, R., Seligman, A. M.: Preparation of a new tetrazolium salt which yields a blue pigment on reduction and its use in the demonstration of enzymes in normal and neoplastic tissue, Cancer Res., 10: 113, 1950.

67) Shear, M.: The structure and function of myoepithelial cells in salivary galnds, Arch. Oral biol., 11: 769, 1966.

68) Shklar, G., Chauncy, H.H.: Papillary adenoma lymphomatosum, a developmental malformation: histochemical evidence, J. Oral Surg., 23: 222, 1965.

69) Sugimura, M., Kawakatsu, K.: Histochemical studies of enzymatic patterns during carcinogenic process in the mouse parotid gland, Arch. Oral Biol.

70）武内忠男, 小川和朗，宇尾野公㬢：病態醉素組 辅化学, 朝會害店.

71) Taki, I. et al.: Histochemical studies of steroid $3 \beta-01$ dehydrogenase of the human ovaries, Am. J. Obstet. Gynecol., 98: 107, 1967.

72) Tandler, B.: Fine structure of oncocytes in human salivary glands, Virchows Arch. Path. Anat., 341: 317, 1966.

73) Tandler, B., Hutter, R.V.P., Erlandson, R.A.: Ultrastructure of oncocytoma of the parotid galnd, Lab. Invest., 23: 567, 1970.

74) Tremblay, G., Pearse, A.G.F.: A cytochemical study of oxyphilic cell and their functional singnificance, Brit. J. Exp. Path., 40: 66, 1959.

75) Tremblay, G., Pearse, A.G.E.: Histochemistry of oxidatine enzyme systems in the human thyroid, with special reference to Askanazy cell, J. Path. Bact., 80: 353, 1960.

76) Walker, D.G.: A survey of dehydrogenases in various epithelial cells in the rat, J. Cell Biol., 17: 255, 1963.

77) Walker, D.G., Seligman, A.M.: Formalin fixation in the cytochemical demonstration 
of succinic dehydrogenase of mitochondria, $\mathrm{J}$.

Biophy Biochem. Cytol., 9: 415, 1961.

78) Willighagen, R.G.J., Thiery, M.: Enzyme histochemistry of ovarian tumors, Am. J. Ob. stet. Gynecol., 100: 393, 1968. 